\title{
DIE BESTEK VAN PRAKTYK VAN DIE KLINIESE VERPLEEGSPESIALIS IN VERLOSKUNDE EN NEONATOLOGIE
}

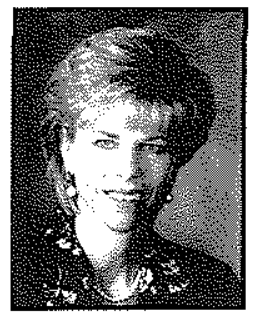

\author{
Dr. Lizeth Roets \\ Ph.D, Lektor, \\ Skool vir Verpleegkunde, \\ UOVS
}

\author{
Dr. Diana du Plessis \\ D.Cur, Lektor, Skool vir Verpleegkunde, \\ RAU
}

\section{SUMMARY}

It is of paramount importance that the clinical nurse specialist, with her advanced knowledge and clinical skills, adapt to the changing South African health care policies and technological progress.

At present, in spite of changing circumstances and expectations, all midwives who have obtained an advanced diploma in Midwifery and Neonatology (thus, clinical nurse specialists) practise within the existing Scope of Practice and regulations for midwives with a basic qualification in Midwifery. The following questions now arise:

- do the professional community, medical practitioners and clinical nurse specialists, have the same expectations concerning the functions of the clinical nurse specialist in Midwifery;

- $\quad$ is the present Scope of Practice of the midwife still relevant in the changing circumstances and does it enable the clinical nurse specialist to practise safely and legally; and

- does the clinical nurse specialist in Midwifery need a different Scope of Practice?

The researcher has examined and described the expectations and functions of the clinical nurse specialist in Midwifery and Neonatology with the aim of formulating directives/recommendations for the Scope of Practice within the South African context.

The data indicates clear similarities and differences in the expectations from the professional community, doctors and clinical nurse specialists with regard to the advanced practice by the clinical nurse specialist.

\section{OPSOMMING}

Die kliniese verpleegspesialis, met haar gevorderde kennis en kliniese vaardighede het noodsaaklik geword om by die SuidAfrikaanse gesondheidsbeleid, tegnologiese vooruitgang en die veranderende omgewing waarin die vroedvrou moet praktiseer, aan te pas.

Tans praktiseer alle vroedvroue wat oor 'n gevorderde diploma in Verloskunde en Neonatologie beskik (kliniese verpleegspesialiste) volgens die bestaande Bestek van Praktyk en regulasies vir vroedvroue wat oor ' $n$ basiese kwalifikasie in Verloskunde beskik, ten spyte van veranderende eise en verwagtinge wat aan haar gestel word. Die vraag ontstaan of:

- die professionele gemeenskap, geneeshere en kliniese verpleegspesialiste dieselfde verwagtinge rondom die funksies van die kliniese verpleegspesialis in Verloskunde, koester;

- die bestaande Bestek van Praktyk van die vroedvrou nog in die veranderende omstandighede relevant en voldoende vir die kliniese verpleegspesialis is om wettig en veilig te praktiseer; en

- $\quad$ of die kliniese verpleegspesialis in Verloskunde ' $n$ andersoortige Bestek van Praktyk benodig.

Die navorser het die verwagtinge en funksies van die kliniese verpleegspesialis in Verloskunde en Neonatologie verken en beskryf met die doel om riglyne/aanbevelings vir die Bestek van Praktyk binne die Suid-Afrikaanse konteks te formuleer.

Die data dui op duidelike ooreenkomste en verskille in die verwagtinge van die professionele gemeenskap, geneeshere en kliniese verpleegspesialiste ten opsigte van die gevorderde praktyk van die kliniese verpleegspesialis in verloskunde en neonatologie.

\section{A G T E R GROND, RASIONAAL EN PROBLEEMSTELLING}

Dit is noodsaaklik om 'n doeltreffende en kosteeffektiewe perinatale gesondheidsdiens aan alle gesondheidsdiensverbruikers daar te stel (Keppler, 1995:17). In Suid-Afrika ondergaan gesondheidsorg indringende veranderinge, met as belangrikste oogmerk, die voorsiening van bekostigbare gesondheidsorg aan alle lede van die bevolking. By die implementering van primêre gesondheidsorg word die vroedvrou as sleutelfigur beskou, aangesien verloskunde ' $n$ integrale deel van voorkomende en bevorderende gesondheidsorg is (Du Plessis, 1993:5). "The nurse is essential to the planning, implementation and evaluation of primary health care in the RSA" (Slabber, 1989:21). Die kliniese verpleegspesialis, met haar gevorderde kennis en kliniese vaardighede het 
noodsaaklik geword om by die Suid-Afrikaanse gesondheidsbeleid, tegnologiese vooruitgang en die veranderde omgewing waarin die vroedvrou moet praktiseer, aan te pas. "Advanced practice nurses, including nurse midwives are marching to the forefront as cost-effective providers perfectly suited to help solve our nation's health care crisis" (Pearson, 1993:23).

Tans praktiseer alle vroedvroue wat oor 'n gevorderde diploma in Verloskunde en Neonatologie beskik (genoem kliniese verpleegspesialiste) volgens die bestaande Bestek van Praktyk (R.2488). Die vraag ontstaan of:

- die professionele gemeenskap (geregistreerde verpleegkundiges met ' $\mathrm{n}$ kwalifikasie in Verloskunde), geneeshere (ginekoloë en algemene praktisyns) en kliniese verpleegspesialiste dieselfde verwagtinge rondom die funksies van die kliniese verpleegspesialis in Verloskunde, koester.

\section{NAVORSINGSDOELSTELLING}

Die doel van die studie was om die verwagtinge en funksies rakende die kliniese verpleegspesialis in Verloskunde te verken en beskryf om sodoende riglyne/aanbevelings vir die Bestek van Praktyk binne die Suid-Afrikaanse konteks te formuleer.

\section{DOELWITTE}

Die navorser het:

- die verwagtinge van die geneesheer en die professionele gemeenskap (geregistreerde verpleegkundiges) ten opsigte van die kennis en vaardigheid waaroor die verpleegkundige na voltooiing van ' $n$ gevorderde kursus in Verloskunde en Neonatologie moet beskik, bepaal;

- die kliniese praktika-vereistes wat die verskillende opleidingskole ten opsigte van ' $n$ kursus in gevorderde Verloskunde en Neonatologie stel, ontleed;

- werklike praktykvoering van die praktiserende kliniese verpleegspesialis, geëvalueer;

- die analise van die wetgewing wat op alle vroedvroue betrekking het, vergelyk met die verwagtinge wat ten opsigte van kliniese verpleegspesialisasie bestaan; en

- riglyne/aanbevelings vir ' $n$ Bestek van Praktyk vir die kliniese verpleegspesialis in verloskunde en Neonatologie binne die Suid-Afrikaanse konteks, geformuleer.

\section{NAVORSINGSONTWERP EN VERLOOP VAN DIE STUDIE}

Die navorsingsontwerp kan as verkennend, beskrywend en vergelykend beskryf word. Die navorsingstegnieke was literatuuranalises, gestruktureerde vraelyste, fokusgroeponderhoude en suiweringsgesprekke.

Die navorsing is in drie fases afgehandel en het as volg verloop:

\section{FASE I}

Tydens Fase 1 is die verwagtinge van die professionele gemeenskap, die geneesheerkorps, opleidingskole en kliniese verpleegspesialiste rakende die funksies van die kliniese verpleegspesialis bepaal. Die fase is in drie stappe afgehandel.

\section{Stap 1}

Tydens Stap 1 is ' $n$ fokusgroeponderhoud oor die funksies van die kliniese verpleegspesialis met kundiges wat aan verloskundige eenhede verbonde is gevoer. Die doel hiervan was om data te verkry om sodoende die semi-gestruktureerde vraelys ten opsigte van die aktiwiteite en funksies van die kliniese verpleegspesialis in Verloskunde saam te stel. Die fokusgroeponderhoud is dus as metode van vraelysontwikkeling gebruik (Kingry, Tiedje \& Friedman, 1990:125), sowel as om triangulasie in die navorsing te bewerkstellig (Morgan \& Spanish, 1984:253).

\section{Steekproefseleksie:}

Die deelnemers aan die fokusgroep is doelgerig geselekteer (Katzenellenbogen, Joubert \& Yach, 1991:82) en is soos volg verkies:

a) Een lid elk vanuit die drie hospitale in Bloemfontein wat oor kraamafdelings beskik. Die hoofverpleegkundige van elke hospitaal se kraamafdeling is deur die navorser genader en sy is versoek om een senior praktiserende vroedvrou te identifiseer wat bereid sou wees om aan die fokusgroeponderhoud deel te neem.

b) Een lid elk vanuit die drie verpleegopleidingskole in Bloemfontein wat betrokke is by die onderrig van Verloskunde en Neonatologie vir voorgraadse en nagraadse verpleegkunde studente.

c) Twee kliniese verpleegspesialiste wat tans binne verloskundige gesondheidsorg praktiseer. Die navorser het hulle doelgerig geselekteer aangesien hierdie twee persone oor 'n Gevorderde diploma en na-basiese graad in Verloskunde en Neonatologie beskik.

d) Twee praktiserende ginekoloë in Bloemfontein waarvan een privaat en die ander in die akademiese opset praktiseer. Die navorser het die twee lede doelgerig geselekteer vanweë hulle belangstelling en betrokkenheid in die opleiding en praktykvoering van vroedvroue.

e) Twee algemene praktisyns wat in die betrokke kraamafdelings in Bloemfontein die meeste bevallings doen en belangstelling in verloskundige opleiding uitspreek. 


\section{Die fasiliteerder:}

Dit is belangrik dat die fasiliteerder van ' $n$ groep bedrewe in groepsleierskap sowel as onderhoudvoering moet wees. Die navorser het egter nie self as fasiliteerder opgetree nie, aangesien sy ' $n$ kenner in Verloskunde is en dus die groep in " $n$ bepaalde rigting kon stuur. Daar is dus op ' $\mathrm{n}$ onafhanklike fasiliteerder wat aan alle vereistes voldoen, besluit.

\section{Verloop van die fokusgroeponderhoud}

Die fasiliteerder het die sessie begin deur die belang van die studie en die insette wat die groepslede lewer, uiteen te sit. Die belang van hul deelname is beklemtoon en die doel van die byeenkoms verduidelik.

Die fasiliteerder het hul rakende die rol van die navorser wat veldnotas geneem en die bandopnames gemaak het, ingelig. Die deelnemers is verder van konfidensialiteit verseker. Hulle was bewus daarvan dat die transkripsie deur ' $n$ persoon wat oor 'n gevorderde kwalifikasie in Verloskunde en Neonatologie beskik en uitgebreide navorsingsvaardighede het, gekontroleer sou word. Daarna sou die data-analise volg waarna die bandopname vernietig sou word.

Hierna is die goed gestruktureerde vraag, wat op die doel van die studie gebaseer is, geskrewe in Engels en Afrikaans aan elke deelnemer gegee en hardop deur die fasiliteerder voorgelees, om ' $\mathrm{n}$ verskeidenheid van response te verkry (Kingry et al. 1990:124).

Die vraag wat gevra is, was:

Wat dink $u$ behoort die kennis en vaardighede van ' $n$ vroedvrou te wees wat oor 'n gevorderde kwalifikasie in Verloskunde en Neonatologie beskik?

Elke lid is die geleentheid gegee om sy opinie te lug sonder om deur groepslede gekritiseer te word (Kingry et al. 1990:124).

Aanvanklik was die deelnemers almal gemaklik en het ontspanne en oop voorgekom. Wat egter opvallend van die twee kliniese verpleegspesialiste was, was hul moedeloosheid en soms selfs aggressiwiteit wat aan die einde van die onderhoud in hul nie-verbale en verbale gedrag na vore gekom het. Gevoelens van frustrasie, veral direk na voltooiing van die kursus in Gevorderde Verloskunde en Neonatologie, word ervaar omdat die kliniese verpleegspesialiste hoë verwagtinge van hul nuwe rol koester en dit dan nie kan uitleef nie. Groepslede bevestig dit so in die onderhoud:

"Maar nou doen ons die kursus en ons werk in 'n plek waar ons alles kan doen en niemand wil ons toelaat om iets te doen nie ... die navorser moet ' $n$ aanbeveling kan doen dat die gevorderde vroedvrou se praktyk dan nou verander:"

Alle beginsels van onderhoudvoering vorm deel van die beginsels van algemene kommunikasie en is deurgaans tydens die fokusgroeponderhoud gehandhaaf. Ten slotte het die fasiliteerder alle deelnemers vir hul deelname bedank (Katzenellenbogen et al. 1991:81).

\section{Stap 2}

Die fokusgroeponderhoud is nou met inbegrip van die veldnotas getranskribeer. Die notas en aantekeninge wat die navorser as waarnemer tydens die fokusgroepsonderhoud afgeneem het (Wilson, 1989:328) is vir validering tydens die transkripsie gebruik (Kingry et al. 1990:125).

' $n$ Inhoudsanalise van die data is vervolgens gedoen aangesien die onderhoud op die manier sistematies, objektief en kwantitatief bestudeer en geanaliseer kon word (Kerlinger, 1986:477; Katzenellenbogen et al. 1991:82). Die transkripsie van die onderhoud is deurgelees en frases wat op die funksies van die verpleegspesialis betrekking het, is onderstreep.

Hierna is ' $n$ algemene lys van idees, waardes, aanhalings en frases opgestel en gekodeer. Reeds vanaf die begin van die transkripsie is met kodering begin sodat herhalende idees, waardes, aanhalings en frases getel kan word en so is kategorieë, groepe en temas ontwikkel. Navorsers beveel aan dat ook ' $\mathrm{n}$ ander persoon, wat met kwalitatiewe navorsingsmetodes bekend is, hierdie proses moet volg om die geldigheid en betroubaarheid van die navorsing te verhoog (Kingry et al. 1990:125; Katzellenbogen et al. 1991:82; Wilson, 1989:230). In dié studie is daar van 'n eksterne kodeerder gebruik gemaak wat kundig in die reduksie en analisering van data vir kwalitatiewe navorsing is.

Die volgende hoofkategoriee is uiteindelik vanuit die fokusgroeponderhoud geïdentifiseer:

a) Opleiding van die kliniese verpleegspesialis in Verloskunde

b) Onderrigfunksie

c) Navorsingsfunksie

d) Administratiewe funksie

e) Outonome praktykvoering

\section{Stap 3}

Nadat die inhoudsanalisie dus afgehandel is, is die resultate van die fokusgroeponderhoud met toepaslike literatuur vergelyk.

Om ' $\mathrm{n}$ geldige en betroubare vraelys saam te stel is ook die Direktief van die SARV (R.1665 van 1979, soos gewysig) asook die Bestek van Praktyk van die vroedvrou (R.2598 van 1984, soos gewysig) aanvullend gebruik. Die volgende regulasies is ook by die samestelling van die vraelys gebruik: 
- R.2488 van 26 Oktober 1990

- R.387 van 15 Februarie 1987 , soos gewysig

- R.425 van 22 Februarie 1985, soos gewysig

Uiteindelik was dit nodig om twee bykans identiese vraelyste te ontwikkel aangesien die navorser ook die werklike praktykvoering van die kliniese verpleegspesialis en die professionele gemeenskap wou blootlê. Die inhoud van die vrarelysitems was identies, maar die vraagformulering tussen die twee vraelyste moes verskil sodat die gewenste respons by die proefpersone verkry kon word (kyk Figuur l).
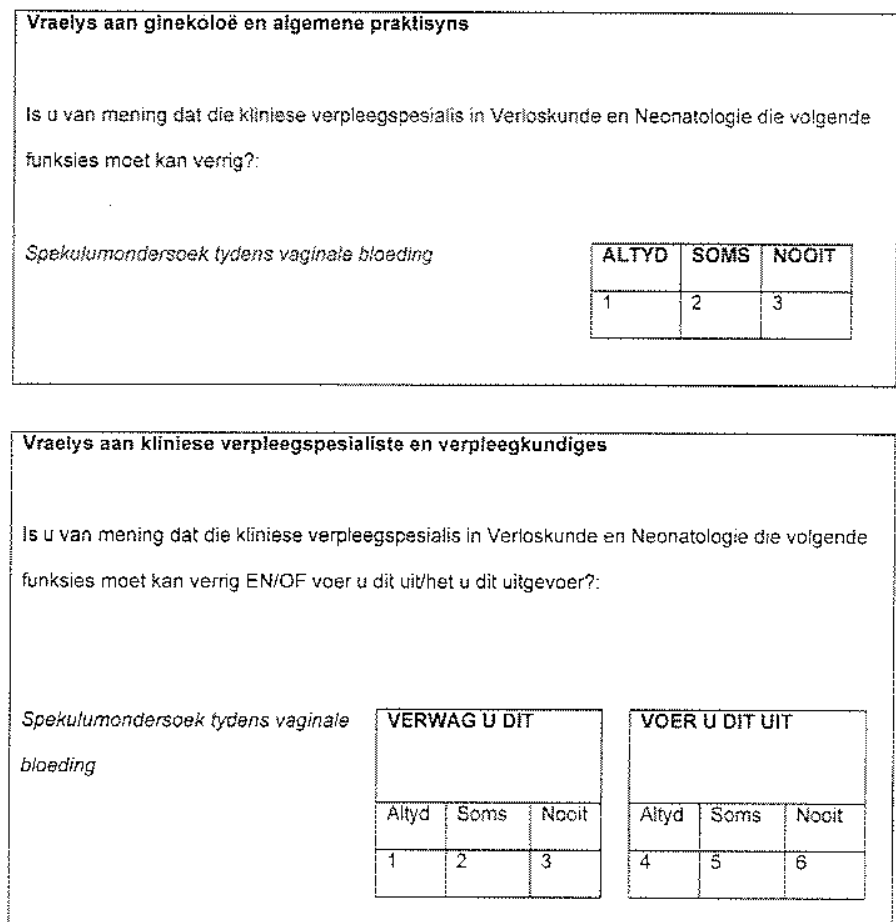

FIGUUR 1 : 'n Voorbeeld van die verskil in vraagformulering tussen die vraelys aan geneeshere en dié aan geregistreerde verpleegkundiges

$\mathrm{Na}$ voltooiing van die vraelys is die steekproef na geneeshere en verpleegkundiges in die res van SuidAfrika uitgebrei om die verwagtinge ten opsigte van die kliniese verpleegspesialis in Verloskunde te bepaal. Die steekproefseleksie is as volg gedoen:

\section{Professionele gemeenskap:}

- proporsioneel ewekansig vanuit die hele verpleegkundige bevolking wat oor ' $n$ kwalifikasie in Verloskunde beskik.

\section{Geneeshere:}

- Proporsioneel ewekansig vanuit alle praktiserende ginekoloë wat by die Suid-Afrikaanse Geneeskundige en Tandheelkundige Raad (SAGTR) geregistreer is.

- Proporsioneel ewekansig vanuit alle praktiserende algemene praktisyns wat by die SAGTR geregistreer is.

\section{Kliniese verpleegspesialiste:}

- Proporsioneel ewekansig vanuit alle kliniese verpleegspesialiste in Verloskunde (vroedvroue met kwalifikasies in gevorderde Verloskunde en Neonatologie).

\section{Opleidingskole:}

- Aan alle opleidingskole wat 'n na-basiese of gevorderde kursus in Verloskunde en Neonatologie aanbied is ' $n$ versoek per brief gerig om ' $n$ kurrikula- en praktika vereistes aan die navorser beskikbaar te stel. Vraelyste is dus nie aan opleidingskole versend nie.

\section{Geldigheid en betroubaarheid}

Polit en Hungler (1987:535) definieer geldigheid as die mate waarin ' $n$ instrument meet wat dit veronderstel is om te meet. Leiniger (1987:34) beskou geldigheid in kwalitatiewe navorsing weer as die mate waartoe die data inligting, kennis en begrip van die persone wat bestudeer word, verskaf.

Die beste kontrole vir die geldigheid van kwalitatiewe navorsing is die presiese aanwending van spesifieke standaarde by die versameling van data in die veld. Die navorser het reeds " $n$ kwalitatiewe studie voltooi en die nodige vaardighede in data-insameling en -analise bemeester. Meer as een data-insamelingstegniek is vir die doeleindes van die studie gebruik en oorweging is aan alle moontlike data geskenk (Lo Biondo-Wood \& Haber, 1990:203).

Die essensie van die geldigheid van die navorser bly egter in die gesag van die navorser gesetel (Krefling, 1991:220). Met ander waarde die "ek was daar" element. Die geldigheid van die navorser is dus belangrik.

Betroubaarheid word weer verseker wanneer ' $n$ onafhanklike navorser onder soortgelyke omstandighede tot dieselfde gevolgtrekkings sou kom (Woods \& Catanzaro, 1988:137). Verifiëring is die kriteria vir presiesheid en dui op die leiding van ' $n$ ander navorser wat die besluitnemingsproses van die oorspronklike navorser gevolg het om tot dieselfde gelykstaande gevolgtrekkings te kom nadat dieselfde stel data aan hom verskaf word (Wilson, 1989:475; Kirk \& Miller, 1986:14). 'n Onafhanklike kodeerder is dus by die studie betrek.

Geldigheid van die meetinstrument (vraelys) self, word weer verkry nie deur ' $n$ spesifieke instrument nie, maar deur die instrument se gebruik in ' $n$ bepaalde situasie. Geen instrument is dus volkome geldig nie, maar daar moet gepoog word om dit so geldig moontlik te maak (Burns \& Grove, 1987:294). Die navorser het die geldigheid van die inhoudelike aspekte getoets en verhoog deur verskeie maatreëls in te bou.

Die betroubaarheid van " $n$ instrument is die mate wat " $n$ 
instrument voortdurend meet wat dit veronderstel is om te meet. Die instrument (vraelys) moet dus die konsep van belang meet (Burns \& Grove, 1987:291). Verskeie maatreëls is ook hier ingebou om betroubaarheid te verseker.

\section{FASE 2}

\section{Doel}

Die vraelyste is verwerk om sodoende te bepaal:

- wat die verwagtinge van die kliniese verpleegspesialis ten opsigte van haar eie rol en taak is;

- hoe hierdie verwagtinge vergelyk met die verwagtinge van ander geregistreerde verpleegkundiges wat oor ' $\mathrm{n}$ basiese kwalifikasie in Verloskunde beskik;

- hoe die verwagtinge van die kliniese verpleegspesialis met dié van die geneesheerkorps ooreenstem; en

- of die verwagtinge van die kliniese verpleegspesialis met werklike praktykvoering ooreenstem.

\section{Geldigheid en betroubaarheid}

Tydens hierdie fase is daar ook aan alle vereistes vir geldigheid en betroubaarheid, soos in die literatuur beskryf, voldoen. Die data-analise is deur die biostatistiekdiens van die Universiteit van die OranjeVrystaat gedoen terwyl die kodering van die vraelyste deur die navorser self gedoen en daarna aan 'n onafhanklike persoon vir kontrole oorhandig is.

\section{Resultate}

Geneeshere en vroedvroue (kliniese verpleegspesialiste en geregistreerde verpleegkundiges) stem saam oor die mees basiese funksies wat normaalweg deur alle praktiserende vroedvroue verrig word, maar wanneer meer "toegepaste" ondersoeke (sonar ondersoeke, biofisiese profiele en oksitosien toetse) ter sprake kom, is daar egter uiteenlopende verwagtinge (kyk Figuur 2). Slegs 'n paar voorbeelde van verskillende verwagtinge sal vervolgens bespreek word.

\section{Verskille ten opsigte van diagnostiese toetse en diagnosering}

Die verwagtinge van die kliniese verpleegspesialiste is konstant hoër as dié van die ginekoloë en algemene praktisyns. So byvoorbeeld verwag $51,4 \%$ van kliniese verpleegspesialiste om biofisiese profiele te kan doen teenoor die verwagting van die ginekoloë $(7,4 \%)$.

Net so het die interpretasie sowel as die behandeling van geïdentifiseerde probleme die verskil in verwagtinge tussen die geneesheer- en die

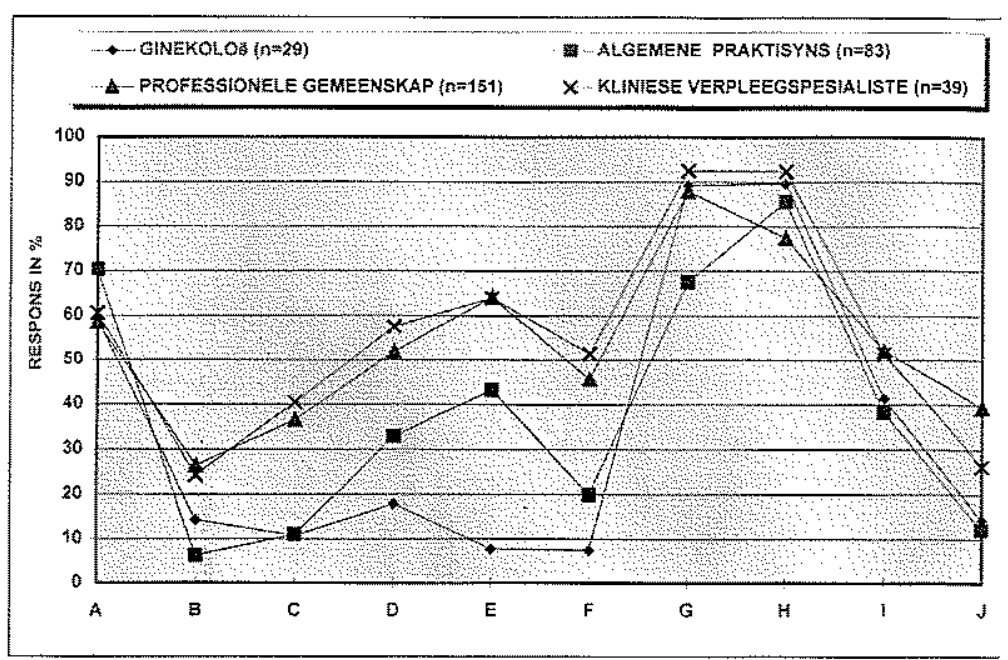

$A=$ NON-STRESS TOETS
$B=$ OKSITOSIEN TOETS
$C=$ SONARONDERSOEK
$D=$ AMNIONSINTESE ASSISTEER
C DOPPLER
$F=$ BIO-FISIESE PROFIEL
$G=$ INDUSEERBAARHEID BEPAAL
$H=$ KARDIOTOKOGRAAF OPSTEL
$I=$ KOPVELELEKTRODE AANWEND
$J=$ INTRA-UTERIENE DRUKKATETER
NPLAAS

FIGUUR 2: Verwagtinge ten opsigte van die uitvoer van die diagnostiese toetse

verpleegkundige korps aangedui.

Dit wil voorkom asof Suid-Afrikaanse ginekoloë en algemene praktisyns van mening is dat die kliniese verpleegspesialis nie nodig het om te alle tye die resultate van diagnostiese toetse te interpreteer nie (kyk Figuur 3). Tog verwag al die ginekoloë en algemene praktisyns dat die kliniese verpleegspesialis wel verpleegdiagnoses korrek moet formuleer.

$\rightarrow$ GINEKOLOQ ( $n=29$ ) $\rightarrow$ ALGEMENE PRAKTISYNS $(n=83$ )

A-PROFESSIONELE GEMEENSKAP $\{n=151\} \quad \times$ KLINIESE VERPLEEGSPESIALISTE $(n=39)$

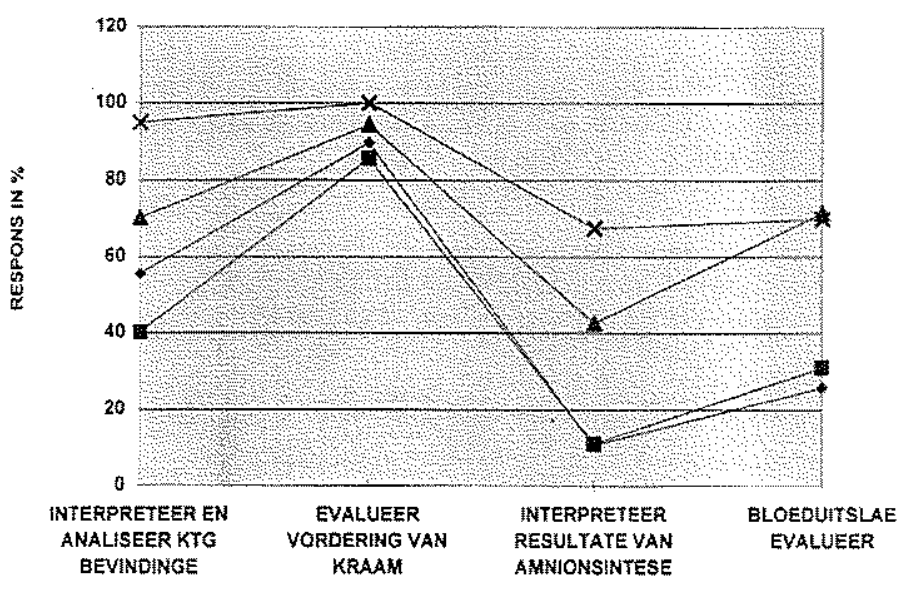

FIGUUR 3: Verwagtinge ten opsigte van die interpretasie van diagnostiese toetse 


\section{Implikasies vir die praktyk}

Hierdie inkongruensie het die volgende implikasies vir die praktyk:

\section{Ante-/intrapartum}

Die analise van ' $n$ kardiotokograafgrafiek, wat direk met die intrapartumperiode verband hou, is volgens die geneesheerkorps nie ' $n$ belangrike vereiste ten opsigte van die vaardigheid van die kliniese verpleegspesialis nie, terwyl kliniese verpleegspesialiste dit as belangrik beskou. Die geneesheerkorps verwag dus dat die kliniese verpleegspesialis verpleegaksies moet implementeer sonder dat hul nodig het om enige interpretasie van data of diagnostiese toetse te maak. Interpretasie van data moet dus in die hande van die geneesheer gelaat word, ten spyte daarvan dat dit die verpleegkundige is wat konstante, deurlopende pasiëntsorg, in die afwesigheid van die geneesheer, moet lewer, abnormaliteite moet kan herken en pasiënte vroegtydig moet kan verwys.

\section{Die hantering van gekompliseerde verlossings}

Duidelike teenstrydige verwagtinge rondom hierdie funksie van die kliniese verpleegspesialis is aangetoon. Kliniese verpleegspesialiste $(79,5 \%)$ verwag dat gekompliseerde verlossings, met spesifieke verwysing na stuitverlossings deel van hul kliniese praktyk moet vorm terwyl ginekoloë $(13,8 \%)$ en algemene praktisyns $(27,4 \%)$ nie dieselfde verwagting het nie (kyk Figuur 4).

Deur die afwenteling van dienste na plaaslike owerhede moet verpleegkundiges of kliniese verpleegspesialiste wat in dié dienste werksaam is, egter in staat wees om gekompliseerde verlossings te behartig. Om klinies vaardig te bly moet die kliniese verpleegspesialis gekompliseerde bevallings behartig om haar selfvertroue en kliniese vaardigheid te behou en om "die komplikasies wat verband hou met swangerskap, baring en die puerperium te voorkom" (R.2598 van 1984, soos gewysig).

\section{Die uitvoer van sekere "gevorderde prosedures"}

Die kurrikula van opleidingskole wat ' $\mathrm{n}$ gevorderde

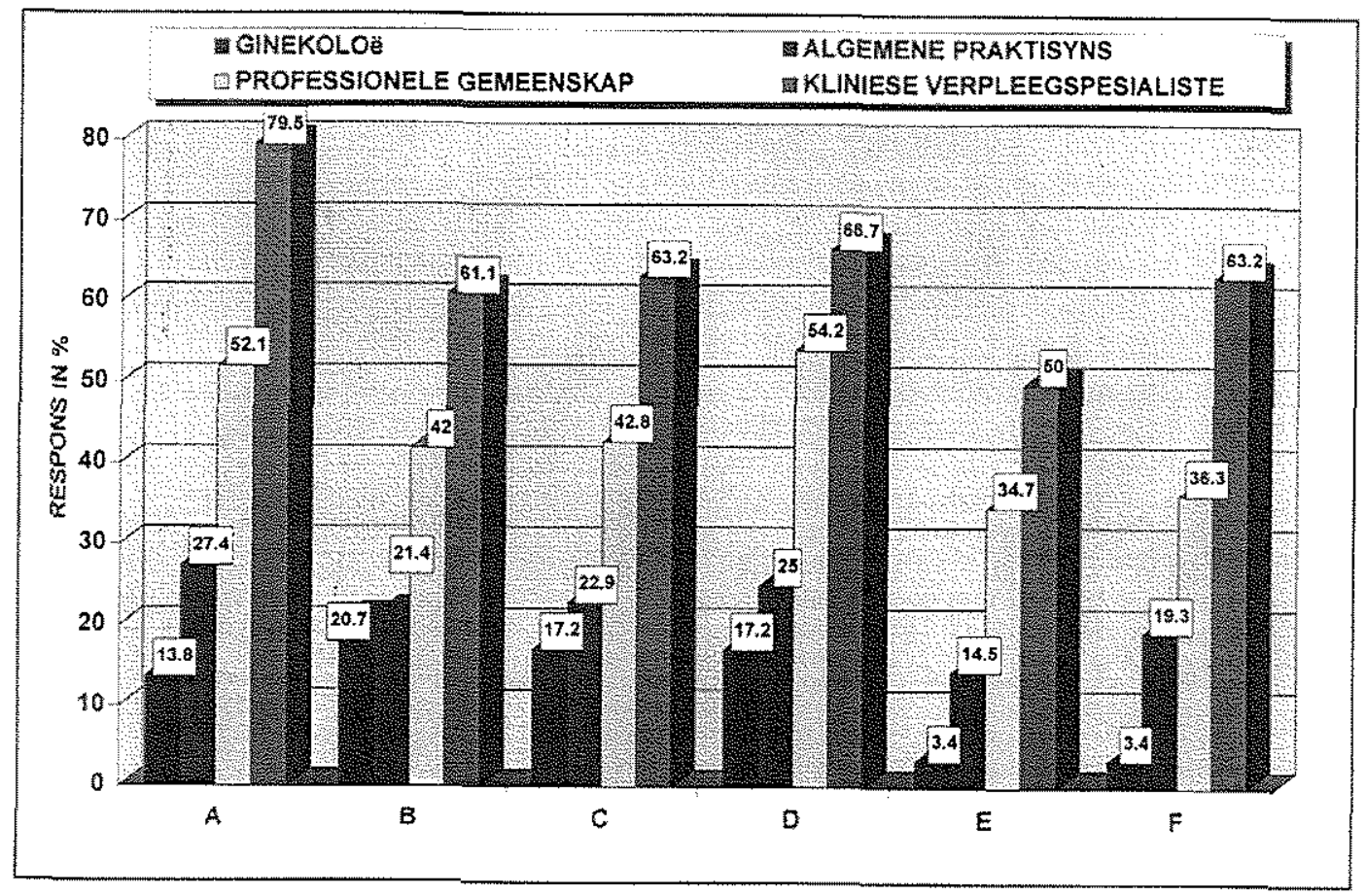

$A=$ STUITPRESENTASIE
$B=$ AANGESIGSPRESENTASIE
$C=$ OKSIPITO POSTERIOR
(BLYWEND)
$D=$ MEERVOUDIGE
SWANGERSKAPPE
$E=$ TANGVERLOSSINGS
$F=$ SUIEREKSTRAKSIES

FIGUUR 4: Verwagting ten opsigte van die hantering van gekompliseerde verlossings (Respondente wat van mening was dat die kliniese verpleegspesialis die verlossings altyd moet kan doen) 
kursus in Verloskunde en Neonatologie aanbied, toon dat daar van die kliniese verpleegspesialis verwag word om teoretiese kennis en vaardigheid in die uitvoer van "gevorderde prosedures" te verkry. Sy moet dus " $n$ plasenta manueel kan verwyder, " $n$ eksterne kering uitvoer en byvoorbeeld by ' $n$ keisersnit assisteer. Die kliniese verpleegspesialis beskik dus na voltooiing van dié kursus oor voldoende kennis en vaardigheid om "gevorderde prosedures" uit te voer.

In teenstelling blyk dit dat die geneesheerkorps die vermoëns van die kliniese verpleegspesialis onderskat, en oënskynlik geen onderskeid tref tussen 'n vroedvrou wat die basiese kursus voltooi het en een wat oor 'n gevorderde kwalifikasie beskik nie. Hulle verwag nie van haar om hierdie "gevorderde aksies" uit te voer nie (kyk Figuur 5). Die kliniese verpleegspesialis wat binne hospitaalverband praktiseer, beleef erge frustrasie (McKee et al. 1992:199) aangesien sy voel dat sy oor die nodige kennis en vaardigheid beskik, maar nie "toegelaat" word om haar praktyk te beoefen nie ten spyte daarvan dat sy verantwoordelikheid en aanspreeklikheid vir haar optrede aanvaar en volgens haar Bestek van Praktyk optree.

Hierdie verskille identifiseer ' $n$ potensiële konflikarea aangesien daar van die vroedvrou verwag word om harmonieus met ander lede van die gesondheidspan saam te werk (Searle, 1987:253), ten spyte daarvan dat daar wyd uiteenlopende persepsies oor haar kundigheid en vermoëns bestaan.

\section{Die outonomiteit van die kliniese verpleegspesialis}

Totaal uiteenlopende verwagtinge ten opsigte van
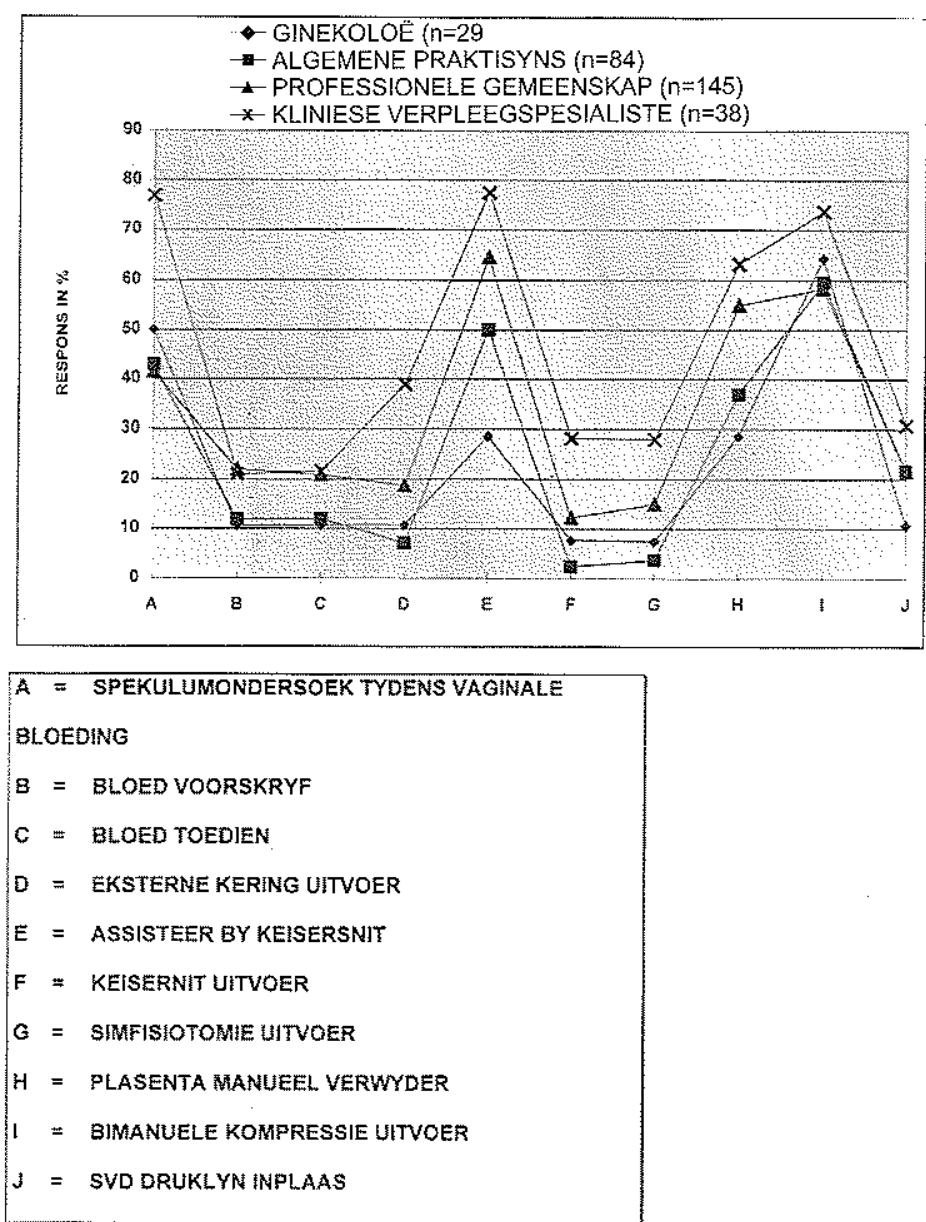

FIGUUR 5: Verwagting ten opsigte van die uitvoer van spesifieke gevorderde verpleegaksies

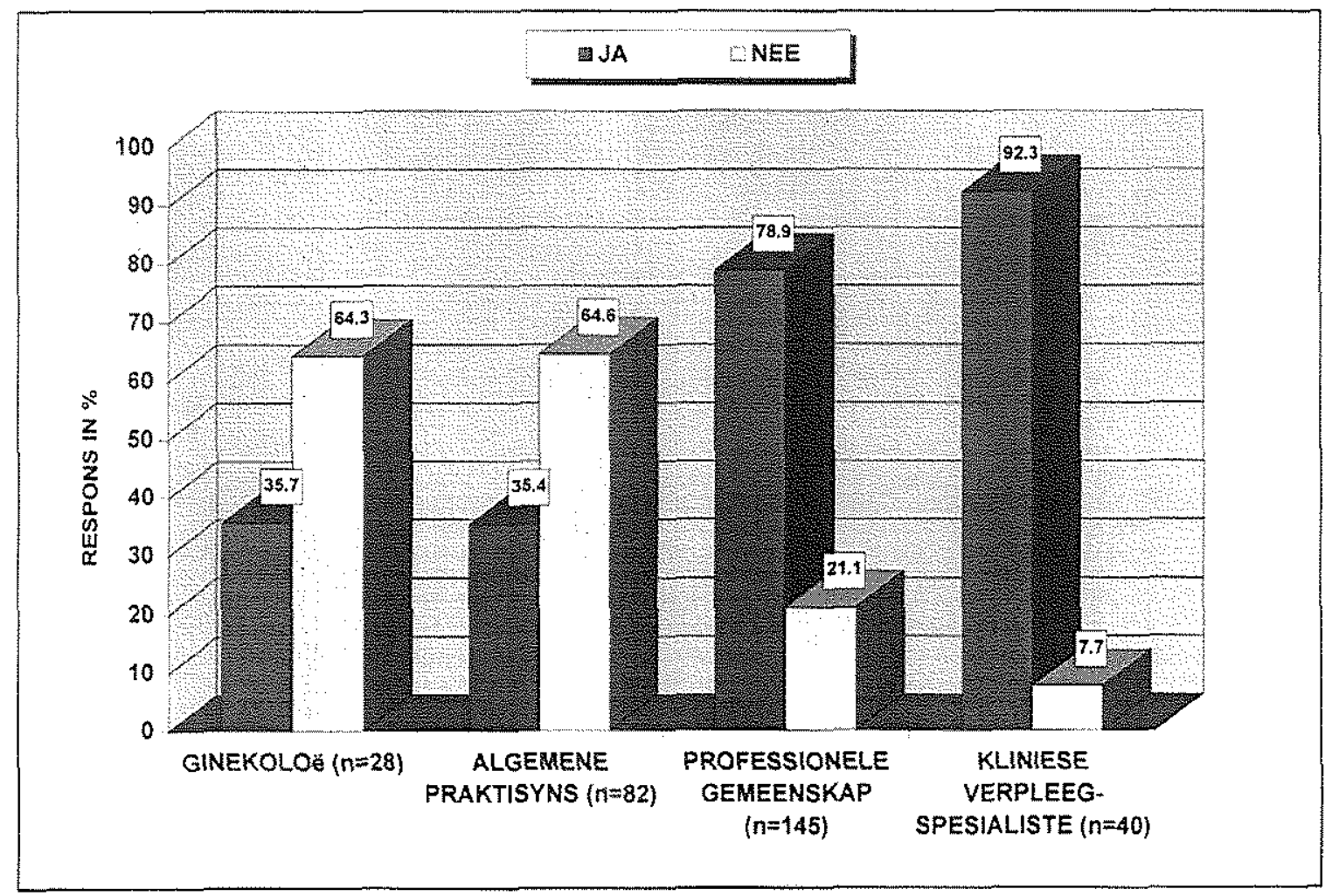

FIGUUR 6: Outonome praktykvoering deur die kliniese verpleeg-spesialis 
outonome praktykvoering deur die kliniese verpleegspesialis is waargeneem. Die kliniese verpleegspesialis $(92,3 \%)$ verwag om outonoom te praktiseer terwyl die ginekoloë $(35,7 \%)$ en die algemene praktisyns $(35,4 \%)$ nie hierdie verwagting koester nie (kyk Figuur 6).

Hierdie verskille verklaar moontlik waarom geneeshere ander outonome handelinge deur die kliniese verpleegspesialis ook bevraagteken. Die resultate weerspieël die argument dat die vroedvrou vir praktykvoering van die geneesheer afhanklik is, ten spyte daarvan dat statutêre voorsiening outonome praktykstatus aan die vroedvrou verleen.

Die outonome praktyk van die kliniese verpleegspesialis impliseer dat sy nie die geneesheer se ondergeskikte is nie, maar dat sy as onafhanklike praktisyn wedersydse verantwoordelikheid tesame met die geneesheer vir die versorging van haar pasiënt aanvaar, terwyl sy aanspreeklikheid vir haar optredes in die samewerkende situasie aanvaar. Sy is dus ' $n$ outonome praktisyn wat onafhanklike besluite ter bevordering, handhawing en herstel van die pasiënt se gesondheid neem.

\section{Die kliniese verpleegspesialis as konsultant}

Die primêre funksie van die kliniese verpleegspesialis is om die gaping tussen teorie en praktyk te oorbrug om sodoende kliniese vakkundigheid by die personeel te bevorder (Fife \& Lemmer, 1983:15). Konsultasie word beskou as die primêre proses waardeur hierdie doel bereik kan word. Deur gebruik te maak van die kliniese verpleegspesialis as konsultant word verseker dat 'n breë basis van inligting verkry word om sodoende probleemoplossing te vergemaklik (Van der Westhuizen, 1994:32).

Strydig hiermee blyk dit dat $64,3 \%$ van ginekoloë en $49,4 \%$ van algemene praktisyns van mening is dat die kliniese verpleegspesialis nie as konsultant behoort op te tree nie (kyk Figuur 7).

Dit wil dus voorkom of die geneesheerkorps nie die kliniese verpleegspesialis in die rol van of outonome praktisyn of as " $n$ vakkundige beskou nie.

Die kliniese verpleegspesialis in Verloskunde word tans ten opsigte van haar spesialiteitsvaardighede onderbenut. Haar vlak van kennis en vaardighede is volgens hierdie navorsingsbevindinge onbekend aan geneeshere, die professionele gemeenskap en die Nasionale gesondheidsbeleidmakers.

\section{FASE 3}

Gevolgtrekkings, aanbevelings en riglyne

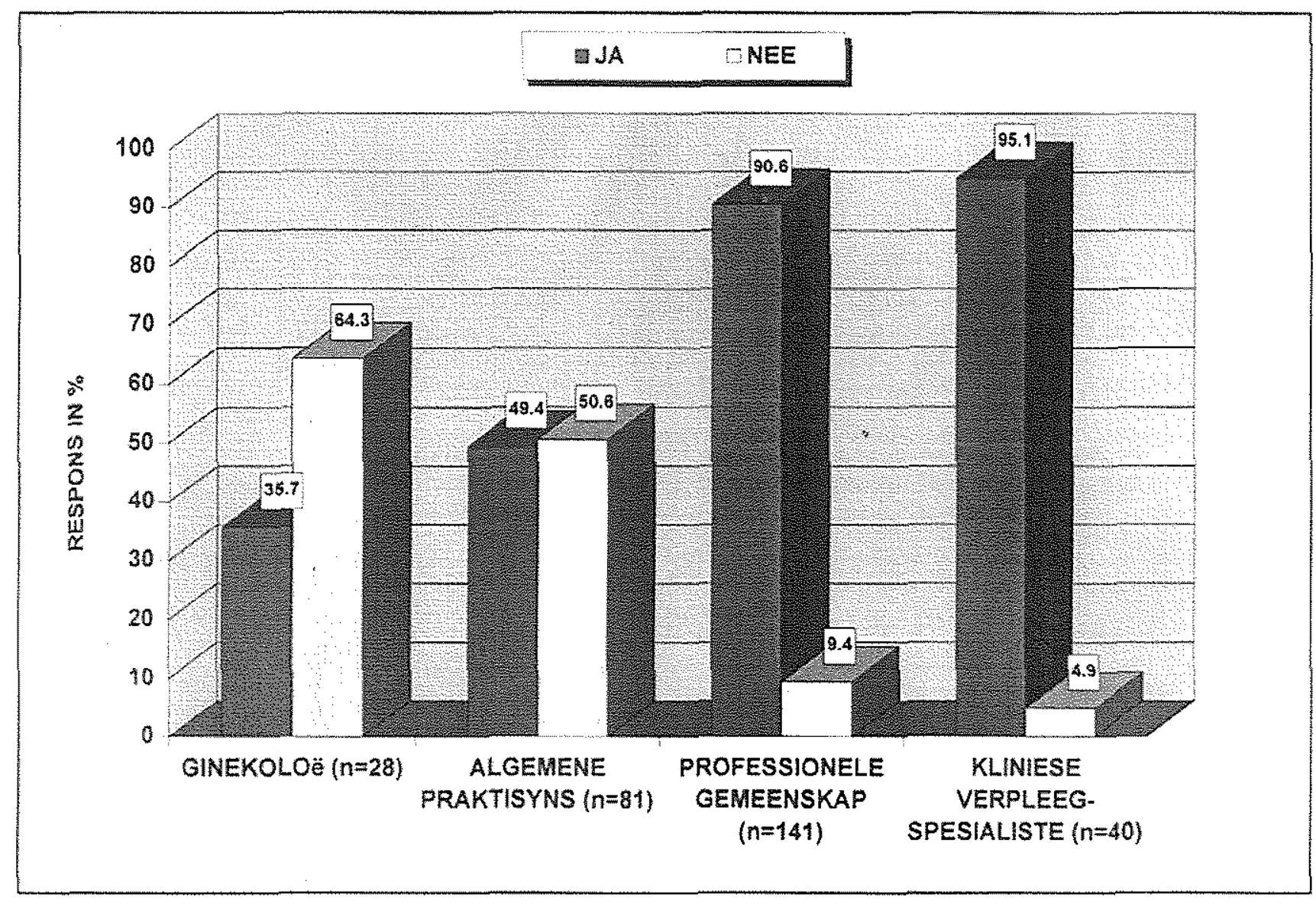

FIGUUR 7: Verwagting dat die kliniese verpleegspesialis in Verloskunde en Neonatologie as konsultant moet optree 
"Met die nodige ondersteuning en samewerking kan die kliniese verpleegspesialis die koste van gesondheidsorg verlaag, funksionering van die pasiënt en familie verhoog en groter werksbevrediging by die personeel, wat direkte pasiëntsorg gee, verskaf. Ongelukkig is daar ' $n$ verdraaide persepsie van die funksies van die kliniese verpleegspesialis" (Van der Westhuizen, 1994:32).

\section{Die bestek van praktyk van die vroedvrou}

Die primêre doelstelling van die studie, naamlik die skryf van riglyne vir 'n Bestek van Praktyk vir die kliniese verpleegspesialis in Verloskunde en Neonatologie, is deur die respondente van die studie as 'n baie belangrike vereiste gestel. Respondente in alle kategorieë was van mening dat "die kliniese verpleegspesialis in Verloskunde op 'n hoër vlak as die gewone vroedvrou praktiseer en 'n ander bestek benodig". Alhoewel geneeshere nie veel meer van 'n kliniese verpleegspesialis as 'n gewone vroedvrou verwag nie, is hulle ook van mening dat 'n andersoortige Bestek van Praktyk vir die kliniese verpleegspesialis benodig word.

Die kliniese verpleegspesialis daarenteen stel hoër eise aan haarself en die professionele gemeenskap het hierdie verwagtinge ondersteun. Desondanks, is albei groepe van mening dat die huidige Bestek van Praktyk beperkend is.

Die kliniese verpleegspesialis praktiseer volgens R.378, R.2598 en R.2488 as outonome praktisyn. Dié regulasies rig haar aksies en stel haar in staat om binne primêre verloskundige gesondheidsorgverband te praktiseer. Regulasies en wetgewing is noodsaaklik, maar: "... to define a scope of practice can be hazardous because technological advances and the dynamic nature of nursing bring about changes in practice impossible to accommodate in a list of procedures or tasks. To express the scope of practice of nursing in lists and procedures negates the real nature of nursing and considers the technical aspects only" (Searle, 1986:172).

\section{Implikasies}

Dit blyk dat die kliniese verpleegspesialis in Verloskunde en Neonatologie 'n "andersoortige" bestek benodig ten einde verwarring en beperking van praktykvoering uit te skakel. Die navorser is van mening dat duidelike riglyne aan die verpleegspesialis en moontlik ook aan die geneesheer verskaf moet word om die vermoëns van die kliniese verpleegspesialis aan te toon.

\section{Aanbevelings/riglyne}

- 'n Sertifikaat kan aan die kliniese verpleegspesialis na voltooiing van haar kursus toegeken word, waarop die spesifieke kliniese vaardighede waaroor sy beskik, aangetoon word. Dié sertifikaat van bevoegdhede moet aan die Suid-Afrikaanse Verpleegstersvereniging (nou DENOSA), Genootskap vir Vroedvroue, Mediese en Tandheelkundige Raad en aan die beleidmakers verskaf word.

- Die Bestek van Praktyk moet op informele en formele wyses aan die geneesheerkorps deur middel van simposia, kongresse, vakliteratuur en lekepublikasies kommunikeer word.

- Kliniese verpleegspesialiste moet hulself in 'n belangegroep organiseer wat:

- beding vir'n eiesoortige loopbaanstruktuur;

- aandring op erkenning binne die herstrukturering van gesondheidsdienste;

- beding om groter betrokkenheid by die heropleiding van verpleegkundiges binne primêre gesondheidsorgklinieke; en

- hulle aanwendingsmoontlikhede, aanvullend tot (buitelandse) geneeshere, aan alle beleidmakers, verduidelik.

- Regulasies wat op die praktyk van die kliniese verpleegspesialis betrekking het, moet hersien en herskryf word om verwarring en waninterpretasie uit te skakel.

- Die navorser stel voor dat indien daar slegs een stel regulasies vir alle vroedvroue moet geld (Dörfling, 1993:143) daar 'n definitiewe onderskeid in die registrasiesertifikat van die kliniese verpleegspesialis moet bestaan om sodoende die bevoegdhede van die verpleegspesialis in Verloskunde en Neonatologie te beskryf. Indien nuwe regulasies nie geskryf word nie, is aanpassings en uitbreiding van die bestaande regulasies nodig.

\section{Outonome praktykvoering}

Dit blyk dat daar beduidende verskille tussen die geneesheerkorps en verpleegkundiges se verwagtinge rakende "gevorderde" praktykvoering in Suid-Afrika bestaan. Terwyl die kliniese verpleegspesialiste en die professionele gemeenskap hulle ten gunste van die outonomie van die kliniese verpleegspesialis uitspreek, is die geneesheerkorps daarteen gekant. Die moontlike oorsake van die geneesheerkorps se teenkantig blyk uit die data te wyte te wees aan:

- Onkunde oor die Bestek van Praktyk van die kliniese verpleegspesialis;

- Onkunde rakende die opleidingsvereistes van die verpleegkundige wat oor ' $n$ gevorderde kursus in Verloskunde en Neonatologie beskik;

- Onkunde oor die kliniese vaardighede en die vermoëns waaroor kliniese verpleegspesialiste beskik; en 
- Persoonlike bedreiging, soos wat twee geneeshere in hul kommentaar op die vraelys gesê het: "Ons soek nie onnodige kompetisie nie".

Vanuit die navorsingsrespons blyk dit dat geneeshere nie onbetrokke by verloskundige praktykvoering wil wees nie, soos bewys deur die persentasie geneeshere wat op die vraelys gereageer het. Geneeshere blyk egter uit die data wel onkundig oor verloskundige praktykvoering deur die kliniese verpleegspesialis, in besondere, te wees.

\section{Implikasies}

- Die implikasie van hierdie verskille in verwagtinge ten opsigte van die outonomie van die kliniese verpleegspesialis kan tot konflik tussen geneeshere en verpleegkundiges aanleiding gee.

- Dit gee verder aanleiding tot die beperking van die kliniese verpleegspesialis se praktyk, aangesien sy nie toegelaat word om haar praktyk na haar vermoëns te beoefen nie.

- Die verloskundige gesondheidsorgprobleme word ondoeltreffend hanteer vanweë konflikterende doelstellings, gebrek aan ondersteuning en erkenning.

\section{Aanbevelings/riglyne}

- Geneeshere moet inligting rakende die kurrikuluminhoud van gevorderde kursusse ontvang.

- Die kliniese verpleegspesialis kan 'n mentorverhouding met die geneesheer vir ses maande of 'n jaar na haar opleiding sluit. (Soortgelyk aan die huisdoktersjaar van die geneeshere.)

- Die Mediese en Tandheelkundige Raad moet inligting rakende die vlak van spesialisasie van die kliniese verpleegspesialis ontvang. Haar kundigheid en vaardighede moet aan die lede bekend gestel word.

\section{Gevorderde kliniese verpleegaksies}

Opleidingskole onderrig die kliniese verpleegspesialis in "gevorderde" kliniese vaardighede:

"More first degree and Master-level courses are available in a wider range of specialist clinical subjects than ever before. This trends means that higher education is increasingly relevant to practitioners" (Mangan, 1994:78).

Dit blyk dat kliniese verpleegspesialiste onderrig in byvoorbeeld gekompliseerde verlossings, diagnostiese toetse, anatomie, fisiologie en farmakologie ontvang, maar slegs ten dele toegelaat word om genoemde funksies in hul praktyk te beoefen. 'n Aantal faktore blyk hiervoor verantwoordelik te wees:

- Baie kliniese verpleegspesialiste werk in kuratiewe dienste, waar geneeshere geredelik beskikbaar is, en spesialis vroedvroue nie hul praktyk na hul vermoë kan beoefen nie.

- Wetgewing skep verwarring en werk beperkend op die praktykvoering van die kliniese $v$ e r p l e e g spesialis in.

- Geneeshere is onkundig oor die kennis en vaardighede van die kliniese verpleegspesialis en laat haar nie toe om praktykvaardig te bly nie. Redes wat hiervoor aangevoer kan word, sluit die volgende in:

- studente in basiese verpleegkundige opleidingsprogramme sowel as mediese studente ding mee om leergeleenthede;

- privaat pasiënte betaal vir die dienste van die geneesheer, en

- onvoldoende skakeling en kommunikasie tussen geneeshere en verpleegkundiges.

R. 2488 wat stipuleer dat die vroedvrou 'n noodgeval na die beste van haar vermoë hanteer totdat die geneesheer opdaag, kan vir die vroedvrou in primêre gesondheidsorgverband probleme skep, aangesien mediese hulp ontbreek en sy outonome besluite moet neem en uitvoer. Al het sy vaardigheid in hierdie noodoptredes (gevorderde aksies) gedurende haar opleiding bemeester, moet sy voortdurend toegelaat word om in haar praktyk vaardigheid hierin te behou. Vaardighede kan slegs deur inoefening bemeester word (Mulder \& MacKenzie, 1994:46-50).

\section{Aanbevelings/riglyne}

- Die kliniese verpleegspesialis benodig kennis en vaardigheid om verloskundige gesondheidsorg aan alle lede van die bevolking te verskaf. Hiervoor benodig sy uitgebreide kennis oor:

- die wetenskaplike metode van verpleging,

- anatomie, fisiologie, patofisiologie en farmakologie,

- komplikasies in swangerskap, baring en die puerperium en

- neonatologie.

- Kliniese verpleegspesialiste moet deur middel van wetgewing toegelaat word om in hul praktyk vaardig in "gevorderde aksies" te bly en met die hulp van voortgesette professionele opleiding moet nuwe tegnologiese vooruitgang en navorsingsresultate in hul praktyk toegepas word.

- Die kliniese verpleegspesialis moet op datum bly met nuwe ontwikkelinge in Verloskunde deur middel van:

- voorgesette professionele opleiding, en

- die bywoning van simposia en opleidingsprogramme.

"In the Netherlands we witnessed midwives practising the skills they had been taught quite independently of medical involvement" (Carter, 1994:34). 


\section{Die toediening van medikasie}

Kliniese verpleegspesialiste ondervind nie slegs beperking ten opsigte van die uitvoer van spesifieke "gevorderde" kliniese vaardighede nie, maar ook ten opsigte van die voorskryf en toediening van medikasie. Regulasies oor medikasie skep verwarring en beperk sodoende die praktyk van die kliniese verpleegspesialis. Opleidingskole daarenteen voorsien die kliniese verpleegspesialis met die nodige kennis om medikasie wat in alledaagse verloskundige praktykvoering gebruik word, te kan toedien en voorskryf.

Die navorser onderskryf in hierdie studie die mening van Dörfling (1993:143) dat die regulasies net soos die opleidingskole met nuwe verwikkelinge in die praktyk en teorie van verloskundige verpleegkunde tred moet hou en dat praktiserende vroedvroue inspraak in regulasiewysiginge behoort te hê.

\section{Aanbevelings/riglyne}

- Alle vroedvroue behoort per regulasie gemagtig te word om sekere medikasies te kan toedien en voorskryf. Die lys van medikasies moet aangepas word om in die behoeftes van die praktyk van die kliniese verpleegspesialis te voldoen.

- Die kliniese verpleegspesialis moet met die hulp van voortgesette professionele opleiding in staat wees om die nodige medikasies voor te skryf en toe te dien (Dörfling, 1993:144).

- Alle praktiserende vroedvroue sowel as geneeshere moet jaarliks vanaf hulle onderskeie professionele genootskappe 'n stel van alle verbandhoudende regulasies, wat die lys van gemagtigde medikasies insluit, ontvang.

Hierdie aanbevelings mag meebring dat die geneesheerkorps bewus word van die medikasie wat wel deur die vroedvrou voorgeskryf en toegedien kan word, en so onnodige konflik uit die weg ruim.

Die navorser is bewus van die feit dat nuwe regulasies rakende die voorskryf en toedien van medikasies eersdaags sal verskyn (SANC, 1995), maar tydens die skryf van die aanbevelings (April 1996) was die regulasies nog nie beskikbaar nie. Die navorser kan nie voorsien of die aanbevelings ten opsigte van medikasie in die nuwe regulasies vervat is nie.

\section{Navorsing}

Die geneesheerkorps sien nie navorsing as funksie van die kliniese verpleegspesialis nie. Tog is navorsing en die toepassing van navorsingsresultate in die praktyk noodsaaklik om gehalteverpleegsorg te lewer.
- Geneeshere moet bewus gemaak word van die navorsingsfunksie van die kliniese verpleegspesialis en die noodsaaklikheid daarvan om $\mathrm{kwaliteitsversekering} \mathrm{in} \mathrm{verpleegsorg} \mathrm{te}$ verseker en sodoende 'n koste-effektiewe verloskundige verpleegdiens te lewer.

- Die kliniese verpleegspesialis moet:

- as spanlid in navorsingsprojekte optree;

- eie navorsing inisieer;

- navorsingsresultate interpreteer en daaropvolgende toepaslike aktiwiteite koördineer met die doel om die verloskundige praktyk te verbeter.

\section{Voortgesette professionele opleiding}

Alhoewel hierdie navorsing nooit die wenslikheid of die behoefte aan 'n Gevorderde kursus in Verloskunde en Neonatologie ondersoek het nie, is dit tog ' $n$ vraag wat onwillekeurig opduik vanweë die menings van sommige navorsers dat die gevorderde of na-basiese kursus bloot ' $n$ remediëring van die basiese kursus is (Nolte, 1994:14). Die gevolg van hierdie menings is dat erkenning van die vaardighede van die kliniese verpleegspesialis ontbreek.

\section{Aanbevelings/riglyne}

- Die navorser is van mening dat dit noodsaaklik geword het dat die onderskeie beroepsverenigings wat by die opleiding van vroedvroue betrokke is, hierdie saak indringend ondersoek ten einde verskille en verdraaiings in persepsie rakende die funksies en vermoëns van die kliniese verpleegspesialis uit die weg te ruim.

- Indien bogenoemde aanbeveling ten uitvoer gebring word, is voortgesette professionele opleiding van uiterste belang om te verseker dat die kliniese verpleegspesialis in dié vaardighede wat in haar spesifieke praktyk van toepassing is, vaardig bly.

- Alle instansies wat basiese en voortgesette opleidingsprogramme aanbied, behoort by 'n vereniging soos die Genootskap vir Vroedvroue geakkrediteer te word. Dit veronderstel:

- hersiening van basiese en na-basiese opleidingsprogramme;

- hersiening van voortgesette professionele opleidingsprogramme;

- die opleiding van evalueerders en programsamestellers;

- die formulering van kriteria en standaarde waaraan die programinhoud moet voldoen;

- die ontwikkeling van 'n programevalueringstelsel;

- die administrering en uitoefening van beheer; en

- ondersoeke na dissiplinêre stelsels indien die kliniese verpleegspesialis versuim om 
voortgesette professionele opleiding te deurloop.

\section{AANWENDINGSMOONTLIKHEDE VAN DIE KLINIESE VERPLEEGSPESIALIS}

Ten spyte van die huidige onkunde en onderbenutting van die kliniese verpleegspesialis in Verloskunde en Neonatologie, hou die toekoms vir hierdie praktisyn groot belofte in. Terwyl hospitalisasieverblyf van pasiënte verkort en mediese dienste al duurder word, word kwaliteitverpleegsorg in hospitale en kliniekdienste al hoe belangriker. Die kliniese verpleegspesialis kan in beide kuratiewe en binne primêre gesondheidsorgverband met welslae aangewend word. Hulle speel 'n rol in strategieë om koste-effektiewe en kwaliteitgesondheidsorg daar te stel. Die kliniese verpleegspesialis moet dus:

- die funksies van die primêre gesondheidsorg verpleegkundige versterk deur as konsultant en rolmodel op te tree en deur mentorskap teorie- en praktykintegrasie bewerkstellig;

- as konsultant en rolmodel in die kliniese praktyk optree om verpleegkundiges in kuratiewe dienste sowel as primêre gesondheidsorgverpleegkundiges van nuwe ontwikkelinge en navorsingsresultate in Verpleegkunde, bewus te maak;

- as lid van die multiprofessionele span 'n bydrae lewer om spanwerk te bevorder en so pasiëntsorg te verbeter;

- deur onderrig in die kliniese praktyk haar kennis en vaardighede met ander verpleegkundiges deel om kwaliteitsorg te verseker; en

- aanspreeklikheid vir al haar aksies aanvaar en as outonome praktisyn praktiseer.

"The role of the advanced diploma midwife as part of a strong team has been central to this success and is to be encouraged. Our aim is to have one in each of our village clinics" (Wilkonson \& Biyela, 1994:33).

\section{SLOTOPMERKING}

Daar is ' $\mathrm{n}$ dringende behoefte aan loopbaanbevordering vir die kliniese verpleegspesialis, veral in kuratiewe dienste, waarin verandering, spesialisering en kundigheid erken word. Deur gepaste plasing van die kliniese verpleegspesialis in primêre gesondheidsorgverband kan sy, met haar gevorderde kennis en vaardigheid in Verloskunde en Neonatologie, indien sy toegelaat word om na haar vermoëns te praktiseer, 'n waardevolle bydrae tot koste-effektiewe verloskundige gesondheidsorg in Suid-Afrika lewer.

Gesondheidsorg in Suid-Afrika ondergaan indringende veranderinge en die kliniese verpleegspesialis moet haarself as onvervangbaar bewys. Met die werwing van buitelandse geneeshere vir die implementering van 'n stelsel van primêre gesondheidsorg mag die vroedvrou in Suid-Afrika en die kliniese verpleegspesialis in die besonder, haar in ' $\mathrm{n}$ posisie bevind waar sy sal moet bewys lewer van haar kennis, vaardigheid en onvervangbare waarde as verskaffer van pasiëntsorg.

Die beleidmakende rolspelers in gesondheidsorg moet egter van die kliniese verpleegspesialis kennis neem. Indien hulle van die vermoëns van die kliniese verpleegspesialiste bewus was, kon hulle hul regmatige plek ingeneem het om primêre verloskundige gesondheidsorg aan die totale Suid-Afrikaanse bevolking te lewer.

"Can the profession redesign itself, yet preserve its integrity as a separate, identifiable system? The health care environment will turn to alternative solutions to have its needs met. Indeed, the environmental turbulence of today may subside in the future, and the departures we suggest may turn out to be transitional. But the ability to adapt will help the profession remain healthy" (Begun \& White, 1995:13).

\section{BIBLIOGRAFIE}

BEGUN, JW \& WHITE, KR 1995: Altering nursing's dominant logic: Guidelines from complex adaptive systems theory. Complexity and Chaos in Nursing, 2(1), 1995:5-13.

BURNS, N \& GROVE, SK 1987: The practice of nursing research/conduct, critique and utilization. Philadelphia: WB Saunders Co.

CARTER, L 1994: Taking over. Nursing Times, 90(12), 1994:34-36.

DÖRFLING, CS 1993: Wetgewing wat die praktyk van die vroedvrou beheer. Johannesburg: Randse Afrikaanse Universiteit. (D.Cur-proefskrif.)

DU PLESSIS, DW 1993: Voortgesette professionele opleiding vir vroedvroue. Johannesburg: Randse Afrikaanse Universiteit. (D. Cur-proefskrif.)

FIFE, B \& LEMMER, S 1983: The psychiatric nurse specialist. A valuable assest in general hospital. Journal of Advanced Nursing, 13(4), 1983:14-17.

KATZENELLENBOGEN, J; JOUBERT, G \& YACH, D 1991: Introductory manual for epidemiology in Southern Africa. Oxford University Press: Medical Research Council.

KEPPLER, AB 1995: Postpartum care centre: Followup care in a hospital - based clinic. Journal of Obstetric, Gynecologic and Neonatal Nursing, 24(1), 1995:17-21.

KERLINGER, F 1986: Foundations of behavioral research. New York: Holtd, Rinehart \& Winston. 
KINGRY, MJ; TIEDJE, LB \& FRIEDMAN, LL 1990: Focus groups: A research technique for nursing. Nursing Research, 39(2), 1990:124-125.

KIRK, J \& MILLER, ML 1986: Reliability and validity in qualitative research. Beverly Hills: SAGE Publications.

KREFTING, L 1991: Rigor in qualitative research: The assessment of trustworthiness. The American Journal of Occupational Therapy, 45(3), 1991:214-222.

LEININGER, MM 1987: Importance and uses of ethnomethods: Ethnography and ethnonursing research. Recent Advances in Nursing Science, 8(3), 1987:27-37.

LOBIONDO-WOOD, G \& HABER, J 1990: Nursing research, methods, critical approval and utilization; 2 nd edition. St Louis: CV Mosby Co.

MANGAN, P 1994: A watershed in education. Nursing Times, 90(41), 1994:78-80.

McKEE, M; PRIEST, P; GINZLER, M \& BLACK, N 1992: Can out of hours work by junior doctors in obstetrics be reduced. British Journal of Obstetric and Gynecologic, 99, 1992:197-202.

MILNER, I 1993: Appropriate midwifery care for the 1990's. Midwives Chronicle and Nursing Notes, 106, 1993:34-36.

MORGAN, DL \& SPANISH, MT 1984: Focus groups: A new tool for qualitative research. Qualitative Sociologic, 7(3), 1984:253-269.

MULDER, M \& MacKENZIE, J 1994: Beter benutting van die simuleringsfasiliteit: Ken is nie kan nie, gesien ook nie. Curationis, 17(1), 1994:46-50.

NICODEM, C; NKONYANI, T \& BEVERLY, MM 1996: Clinical comments. Nursing News, 20(3), 1996:20-21.

NOLTE, A 1994: Die dilemma van die vroedvrou. Verpleging RSA, $9(11 / 12), 1994: 11-15$.

PEARSON, LJ 1993: 1992-1993 Update: How each state stand on legislative issues affecting advanced nursing practice. The Nurse Practitioner, 18(1), 1992/1993:23-38

SEARLE, C 1987: Professionele praktyk: 'n SuidAfrikaanse verpleegperspektief. Durban: Butterworth Uitgewers (Edms.) Bpk.

SLABBER, CF 1989: Toespraak op 3 April 1989 tydens die Eerste vergadering van die Tiende Raad op
Verpleging. Pretoria: Suid-Afrikaanse Raad op Verpleging.

VAN DER WESTHUIZEN, E 1994: Die kliniese verpleegspesialis: Die ideaal en die realiteit. Verpleging RSA, 9(3), 1994:29-32.

WILKINSON, D \& BIYEALA, A 1994: Improving perinatal outcomes in a rural hospital. Nursing RSA, $9(2): 33-36$.

WILSON, HS 1989: Research in nursing; 2nd edition. California: Addison-Wesley Publishing Co.

WOODS, NF \& CATANZARO, M 1988: Nursing research; theory and practice. St Louis: CV Mosby.

Die Suid-Afrikaanse Raad op Verpleging: Regulasies

- No. R.1665 van 1979, soos gewysig

- No.R.2488 van 26 Oktober 1990

- No. R.387 van 15 Februarie 1987, soos gewysig

- No.R.245 van 22 Februarie 1985, soos gewysig

- No.R.2598 van 1984, soos gewysig 